\title{
Adaptation of ICT Integration Approach Scale to Kosovo Culture: A Study of Validity and Reliability Analysis
}

\author{
Serdan Kervan ${ }^{1}$, Erdoğan Tezci ${ }^{2, *}$ \\ Department of Education Science, Prizren University, Prizren, Kosovo \\ ${ }^{2}$ Department of Education Science, Balıkesir University, Balikesir, Turkey
}

Copyright $\bigcirc 2018$ by authors, all rights reserved. Authors agree that this article remains permanently open access under the terms of the Creative Commons Attribution License 4.0 International License

\begin{abstract}
The aim of this study is to adapt ICT integration approach scale to Kosovo culture, which measures ICT integration approaches of university faculty to teaching and learning process. The scale developed in Turkish has been translated into Albanian to provide linguistic equivalence. The survey was given to a total of 303 instructors [161 (53.1\%) females and $142(46.9 \%)$ males] for the Confirmatory Factor Analysis of the scale. In the first analysis of the scale, fit indices were obtained in support of 3 factors. However, as a result of 4 different modifications made between 8 items, excellent values were obtained for some of the fit indices. For criterion validity, statistically significant differences were found, in terms of the cognitive and cultural dimensions, between the users who don't use technology or use it very limited and the users who often use technology in the teaching and learning process. As a result of Cronbach's Alpha analysis in the context of internal consistency of the scale, high reliability values have been obtained both in the dimensions of traditional, cognitive and cultural integration and throughout the scale. It has been determined that all items are discriminators as a result of the analysis made by the upper group and lower group technique for item discrimination. Results show that the scale supports the 3 factors in Kosovo culture as well and can be used to determine in what context instructors integrate technology in their teaching and learning process.
\end{abstract}

Keywords Information and Communication Technologies, Technology Integration, Confirmatory Factor Analysis

\section{Introduction}

Information and Communication Technologies (ICT) increase student achievement and develop their skills (Ertmer, 1999; Jung, 2005) as well as preparing learners for a transition to information economy and information society (Eurydice, 2004; European Commission, 2000). Especially for the solution of educational problems and the construction of the information society, ICT has begun to be seen as an instrument of educational reform movements and studies are being carried out to integrate ICT into curricula (Kozma, 2005; Law, 2004; Lim \& Chai, 2004; Richardson, 2008; Sahlberg, 2006; Tezci, 2009, 2011a). In this context, it is seen that in schools there is a significant amount of resources devoted to ICT investments (OECD, 2017; World Bank, 2010; Wren, 2017). Investments in ICT-related software and hardware in schools and classrooms provide teachers with easy access to such technologies. Underlying belief is that teachers will integrate ICT into the teaching and learning process in the classroom when they have easy access to ICT-related tools (Ertmer, 1999). Moreover, with the investments made regarding ICT, teachers and instructors have been expected to make a transition from the traditional approach of pedagogical understanding to the constructivist approach (Becta, 2007; Lim \& Chai, 2008; Selwyn, 2008; Tezci, 2011a). In other words, the underlying idea is to design an effective learning environment based on ICT. While access to ICT-related tools and software is important, there is a great deal of evidence showing that access does not guarantee the integration (Albirini, 2006; Brantley-Dias \& Ertmer, 2013; Hermans, Tondeur, van Braak, \& Valcke, 2008; Koh, Chai \& Lim, 2017; Tezci, 2009; 2011b). The inclusion of technology in the class does not guarantee its integration into the teaching and learning process effectively.

Although curriculum development work has been carried out for the effective integration of ICT into curriculum, the presence of ICT in curricula does not mean that the teachers will effectively use these tools in the teaching and learning process. Research has shown that 
teachers do not use ICT in the classroom to help students learn, and they cannot handle technology-based lessons (Ottenbreit-Leftwich, Ertmer \& Tondeur, 2015; Palak \& Walls, 2009; Tezci, 2011a; Ward \& Parr, 2010). In the European Commission (2001) report, it was observed that when teachers could not integrate technology effectively into the lesson, students developed negative attitudes towards these technologies and that these technologies did not have positive effects on the teaching and learning process and led to different problems instead of solving educational problems. For this reason, the context teachers use the technology in, in other words how they integrate technology into the teaching and learning process, is as important as how easy they access technology in the classroom. It is important that teachers have an understanding of technology-based instructional design such as learning from technology or learning with technology (Ringstaff \& Kelley, 2002). Teachers' integration of technology into their class has the potential to impact on the investments made in these technologies and the success of their reform efforts in this area (Erdener \& Gül, 2017). In addition, determining the technology integration approaches of teachers and instructors will contribute to the training of teachers and instructors and to directing investments related to ICT. From this perspective, it was aimed to adapt the ICT Integration Approach Scale (ICT-IAS) by Tezci (2016) to the Kosovo culture, which was developed for the identification of ICT integration approaches of teachers. The Kosovo Republic re-enacted its educational objectives with the new educational law adopted in 2011 (MAShT, 2011). They have included curriculum development studies based on their educational goals. In this context, they also added the Information and Communication Technologies (ICT) course to the curricula. With this course, they aimed at having new objectives such as students to know and use software and hardware related to ICT, students to access and use information by using ICT, and nation to transition to information economy for sustainable development (MASHT, 2016). They also emphasized the use of information technology in students' learning (MAShT, 2012). The success of these reform efforts in Kosovo education is particularly relevant to the context in which instructors in higher education integrate ICT into the teaching and learning process. This process will shed light on a reliable and valid measurement instrument that can be used to determine the teaching and learning process of the instructors in terms of their ICT integration approaches. From this point of view, in the study, an answer for following question was sought: Is ICT-IAS sufficiently reliable and valid for the use of determining ICT integration approaches of instructors in Kosovo universities?

\section{Theoretical Background}

ICT-IAS has been based on the Type I and Type II use of technologies developed by Maddux and Johnson (2005) and the cultural integration approach developed by Yuen (2000). At the basis of ICT's use of Type I; it can be said that if technology access is provided, technology integration will follow this (Ertmer, 1999). Maddux and Johnson (2005: 3) refer to ICT's use of Type I as "Type I usage predominates and uses computing to make traditional teaching methods easier or more efficient". Technology in this approach is designed for purposes such as making the teaching of the teacher easier, saving time, structuring content, and visualizing content (Jonassen, 1991; Tondeur, van Keer, van Braak \& Valcke, 2008). The Type I use of ICT involves applications based on the Traditional Integration (TI) of technology (Tezci, 2016). TI approach is built on learning from technology. Here, the technology is treated as a tutor. The technology use approach based on the TI approach is effective in teaching simple skills (Ringstaff \& Kelley, 2002, p. 3). Design understanding about learning with technology stated as transmitter pedagogy by Bower, Hedberg and Kuswara (2010) includes applications based on TI understanding. Transferring content using PowerPoint or other presentation programs and presenting graphics to students using Excel are typical examples. Teachers who apply the Type I integration approach design and use the tools and software such as Internet, multimedia, web 2.0, and social media for purposes such as content development and facilitation of knowledge acquisition for students. This approach mainly reflects the first phase of ICT adaptation understanding in which technology literacy skills are being studied. If teachers have easy access to technology and know how to use it, it is a reason to think that they can use technology in their lessons (Jung, 2005). For this reason, ICT is designed for teaching the subject matter. It's the teacher's helper.

The Type II use of technology involves the cognitive constructivist practices of technology (Tezci, 2016). Maddux and Johnson (2006, p. 1) define the use of Type II as "Type II applications make new and better ways of teaching available, ways not possible without the use of information technology". Applications of technology based on Type II have been addressed in the context of cognitive constructivist approach-based adaptation (CCI). Here, the technology is designed as a cognitive tool (Jonassen, Howland, Marra, \& Crismond, 2008). Applications based on the use of Type II form the basis of adaptation based on CCI understanding. This adaptation is therefore based on learning with technology. Technology is designed as a cognitive tool for the development of high-level thinking skills (Jonassen, 2000; Tay, Lim, Lim \& Koh, 2012). Teacher does not transmit the content to the students, but design a learning environment that will support learning outcomes (Ertmer \& Ottenbreit-Leftwich, 2013; Jonassen, 1999). Teachers' integration based on this approach is designed for students to manage and direct their own learning (Mishra \& Koehler, 2006). Technology is 
designed for applications such as ill-structured content, interactive environments, problem solving, authentic tasks, real-life situations, scenarios and case studies, research and inquires, scaffolding (Britten \& Cassady, 2005; Liu, Maddux, \& Johnson, 2008; Koehler \& Mishra, 2009). This approach is also consistent with student-centered instructional strategies. The teacher designs an appropriate learning environment for the students and guides the students to their learning. For this reason, the teacher places such technology applications in such a way that she cannot teach without technology and can only achieve learning objectives effectively in this way (Maddux \& Johnson, 2006). Depending on the change in understanding of teaching and learning, teachers design the technology to make the learning of the students easier and more meaningful (Carlson \& Gadio, 2002). They have an understanding of learning environment design based on learning with technology that will facilitate student learning in an integrated manner with student-centered teaching methods. As students undertake their own learning responsibilities, they use technology to demonstrate what they learn. Activities are designed so that they can perform only with technology.

Another factor in ICT integration approaches of teachers is the socio-cultural context. There are a number of studies showing that teachers are influenced by school support, school climate and socio-cultural factors (Davis, Preston \& Sahin 2009; Tezci, 2011b; van Melle, Cimellaro \& Shulha, 2003). Technology integration based on socio-cultural perspective (SCI) is based on Social-Constructivist ICT applications developed by Yuen (2000). Social-Constructivist ICT applications are based on the constructivist learning theory of Vygotsky (1978). Considering that learning occurs in social settings according to social constructivist approach, ICT is designed as a social learning tool (Palinscar, 1998; Woo \& Reeves, 2007). In the integration of ICT based on socio-cultural approach, schools have a culture and class climate based on learning with technology. There is a culture in which collaborative learning, team learning, cooperation and sharing between teachers and students take place (Fullan, 2002; Tezci, 2016). Technology is included not only in classrooms, but in the vision of the school, its mission and its educational programs shared by students and teachers (Hannover Research, 2014). School and class are technology-based learning communities. Learning is carried out using ICT technologies in the process of multicultural communication, as well as various experiences and perspectives within the learning communities (Jonassen, 1999; Jung, 2005; Koh, et al., 2017; Windschilt, 2002). In the SCI approach, students develop communication and collaboration with technology on the basis of learning at both local and international level. Teachers and students receive counseling and help from experts through communication with tools such as discussion environments, e-mail, social media etc. On this basis, the foundations of culture based on learning with technology are developed (Jung, 2005; Tezci 2011b; Woo $\&$ Reeves, 2007).

The Integration based on TI approach includes full technology-based applications, while the CCI includes vacant technology-based applications. With full technology, teachers make applications on the basis of constructing and transmitting information with applications such as drill and practice, tutorials, and simulations. Vacant technology-based integration includes applications such as web 2.0 tools, concept maps, and simulations. Applications based on socio-cultural constructivist perspective include practices based on the creation of a school and class culture and climate that vacant technologies will support the teacher and student development. CCI and SCI based applications support each other. The instructors' placing applications based on cognitive constructivist understanding does not contradict the development of a socio-cultural understanding. For example, the design of the ICT based collaborative learning environment supports $\mathrm{CCI}$ and $\mathrm{SCI}$ understandings. Nevertheless, it is also clear that the necessity of instructors to incorporate practices based on TI approach from time to time does not mean that they have the traditional integration (TI) understanding of ICT.

\section{Methodology}

\section{Participants}

The survey was given to a total of 303 instructors [161 (53.1\%) females and $142(46.9 \%)$ males] who worked in three different universities in Kosovo and voluntarily participated in the study. The professional seniority of instructors varies between 1 year and 26 years. Eighteen of the instructors $(5.9 \%)$ had undergraduate degree, while 136 (44.9\%) of them had masters and $149(49.2 \%)$ of them had $\mathrm{PhD}$ degrees. $79(26.1 \%)$ of the instructors teach in education field, while $53(17.5 \%)$ in economics, 63 (20.8\%) in second language teaching, $40(13.2 \%)$ in information technology, $\quad 34 \quad(11.2 \%)$ in physics-chemistry-mathematics-biology, $13 \quad(4.3 \%)$ in medicine, $12(3.9 \%)$ in law, and $9(3.0 \%)$ in engineering fields. $169(55.2 \%)$ of the instructors indicated that they used the ICT almost or rarely in teaching and learning process, and $136(44.8 \%)$ of them stated that they used the ICT frequently in teaching and learning process. The average weekly time of ICT use by the instructors in teaching-learning process is 4.2 hours.

\section{Data Collection Tools}

ICT integration approach scale has been developed by Tezci (2016) in Turkey. The scale has been based on the Type I and Type II ICT use of Maddux and Johnson (2005) 
and Yuen's (2000) theories of cultural integration. The scale based on these approaches has been developed to determine three different integration approaches. The use of Type I is dealt with as the forms of Traditional Integration (TI), Type II as Cognitive Constructivist Integration (CCI) and Yuen's cultural integration theory as Socio-Cultural Integration approach (SCI). The TI approach involves the use of ICT's Type I. The TI approach includes materials based on learning from technology, such as designing ICT for information transfer, content development, and as a tool that helps the teacher to visualize the lesson. CCI approach is based on the Type II. CCI approach includes materials based on learning with technology, such as accessing information, doing research and analyses, using technology, and presenting what they learn. The SCI approach includes materials based on creating a communication and collaboration among students, among teachers, and between students and teachers and building a cultural environment that will enable learning with technology. The scale consists of 20 items, including 8 items in the dimension of Traditional Integration approach, 7 items in the dimension of Cognitive Constructivist Integration approach and 5 items in the dimension of Socio-Cultural Integration approach. The scale is a 5-point Likert type scale, including the choices of $5=$ absolutely agree, $4=$ agree, $3=$ neutral, $2=$ disagree, and $1=$ absolutely disagree. As a result of the exploratory factor analysis made by Tezci (2016), it was determined that TI dimension explained $20.492 \%$ of the variance, CCI dimension explained $17.699 \%$ of the variance, and CCI dimension explained $7.111 \%$ of the variance. The reliability of the TI dimension for the scale was found to be .87 , reliability of the CCI dimension was .86 , reliability of the SCI dimension was .78 , and overall reliability of the scale was .80 . As a result of confirmatory factor analysis of the scale, some indices were found to be perfect; and some were close to perfect. During the development of the scale, it was reported that there was no inter-items modification.

\section{Data Collection and Analysis}

The data were obtained from the instructors with face-to-face meetings. For the collected data, the linguistic equivalence was first provided. For the internal consistency, the Cronbach Alpha value was calculated in order to provide the reliability of the data related to the scale's implementation in Kosovo Culture. In addition, item-total correlation was also examined.

After providing reliability of the data, the analysis was carried out with the Confirmatory Factor Analysis (CFA). CFA is a process to create a latent variable (factor) from the variables observed through a predetermined model (Bayram, 2010; Büyüköztürk, Şekercioğlu \& Çokluk, 2014). It is aimed to test the pre-determined structural model with CFA and to test the suitability of the scale to the Kosovo culture. CFA has been used to test whether there is a sufficient relationship between the factors determined in Turkish culture, which variables are related to which factors, whether the factors are independent of each other, whether the factors are sufficient to explain the model (Bentler \& Bonett 1980; Tabachnick \& Fidell, 2007). In this study, CFA was used to test the validity of the structure determined by the EFA and to determine the fit of the model, in other words, to test the significance of the relationships between the observed variables and the theoretical structure. Different indices are used to determine the fit of the factor structures. First, Chi-square and $p$-value are examined. Chi-square value can be used when the number of samples is in the range of 250-500 (Bollen, 1989). In this study, data were collected from 303 instructors. AGFI (Adjusted Goodness of Fit Index) and GFI (Goodness Fit Index) can be used as an alternative to Chi-square analysis. AGFI and GFI values close to 1 indicate perfect fit. RMSEA (Root Mean Square Error of Approximation), RMR (Root Mean Residual), and SRMR (Standardized Root Mean Square Residual) are other indices. Another index, CFI (Comparative Fit Index), is used for small samples and it works effectively for small samples because it accounts for sample size. NFI (Normed Fit Index) and NNFI (Non-Normed Fit Index) provide a comparison without having to rely on the assumptions required by the Chi-square distribution. PGFI (Parsimony Goodness-of-Fit Index) is another index that provides information on the simplicity of the model (Bollen, 1989; Hoyle 1995; Jöreskog \& Sörbom 1996; Tabachnick \& Fidell, 2007).

In order to determine the item discrimination of the scale to which the adaptation to Kosovo culture was made, the upper group and lower group technique was used with a $27 \%$ criterion. For the discrimination of each item and each dimension (TI, CCI, and SCI) and for the discrimination of the items, the difference between the groups formed by the technique of $27 \%$ was analyzed by independent-samples $t$ test. A correlation analysis was used to determine whether there was a relationship between ICT integration approaches. In addition, ANOVA was performed according to the frequency of weekly ICT use for educational purposes.

\section{Results}

\section{Linguistic Equivalence Study}

In order to adapt the scale developed in Turkish to the culture of Kosovo, firstly linguistic equivalence has been provided. Geisinger (1994) and Iyengar (1993) pointed to the reliability and validity problems arising from different cultural and language problems in scale adaptation. Researchers in some studies (Asan, Ekşi, Doğan, \& Ekşi, 2013; Meyer \& Eley, 2006; Schellhase, 2009; Tezci, 2009) 
determined different factor structures other than original factor structures in the analysis of reliability and validity stemming from the linguistic and cultural differences. Albanian is one of the most widely spoken languages in Kosovo where this research is conducted. Problems can arise in the reliability and validity of the scale due to the reasons arising from the linguistic difference and the translation of the scale items. In addition to being geographically diverse, Kosovo also has different cultural characteristics such as language, religion and tradition. The context of the use of language may also vary. Research (Gillani 2000; Heemskerk, Brink, Volman \& Ten Dam, 2005; Reeves, 1997) pointed to cultural differences in practices and perspectives relevant to ICT. For this reason, reliability and validity must be examined before direct use of a scale in a different culture (Beaton, Bombardier, Guillemin, \& Ferraz, 2000). Some researchers point out that factor structures of self-reported scales are not stable (Carmines \& Zeller, 1979; Taylor, Bagby \& Parker, 2003). For this reason, firstly, linguistic equivalence was examined. In order to ensure linguistic equivalence, first of all, scale was translated from Turkish to Albanian because Albanian is one of the languages spoken in Kosovo as well as Turkish. The translation of the scale was made by the translators who are expert in Turkish and Albanian. The translation of the scale was checked by the researchers and the Albanian language experts. In this checking process, no modifications were made in the Albanian version of the scale. Five instructors who speak both Turkish and Albanian were given the versions in both languages and asked to answer the items separately. Then they were asked whether there was any discrepancy between the items in both versions. The answers to both versions (Turkish and Albanian versions) were the same. All five instructors indicated that the expressions (each item) given in both languages measure the same properties. After the feedbacks taken from the instructors, no modifications were made in the items of the scale. Turkish, Albanian, and English versions of the scale are provided in Appendix 1,2 and 3 .

\section{Reliability Analysis}

The Cronbach Alpha reliability for the three factor models and overall scale were examined. As a result of the analysis, the Cronbach Alpha was found to be .90 in the dimension of Traditional Integration approach, .91 in the dimension of Cognitive Constructivist Integration approach, and .91 in the dimension of Socio-Cultural Integration. The overall reliability of the scale was .89 . The results of the analysis are presented in Table 1.

Table 1. Descriptive and Reliability Analysis

\begin{tabular}{|c|c|c|c|c|c|c|}
\hline Item No & Mean & SD & Skewness & Kurtosis & Item-Total Correlation & Cronbach's Alpha \\
\hline ICT-TI1 & 4.13 & .91 & -1.176 & 1.070 & .664 & \\
\hline ICT-TI2 & 4.09 & .97 & -1.196 & 1.102 & .726 & .877 \\
\hline ICT-TI4 & 3.85 & 1.09 & -.562 & -.919 & .572 & \\
\hline ICT-TI9 & 4.01 & .95 & -.784 & -.019 & .715 & \\
\hline ICT-TI13 & 4.09 & 1.05 & -.927 & -.305 & .489 & \\
\hline ICTTI-14 & 3.93 & .89 & -.730 & .078 & .605 & \\
\hline ICT-TI16 & 4.12 & .93 & -1.106 & .743 & .660 & \\
\hline ICT-TI18 & 4.23 & .85 & -.962 & .292 & .667 & \\
\hline ICT-TI - Total & 4.06 & .69 & -1.059 & .642 & & \\
\hline ICT-CCI3 & 3.46 & 1.15 & -.332 & -.332 & .743 & .909 \\
\hline ICT-CCI5 & 3.29 & 1.231 & -.170 & -.170 & .692 & \\
\hline ICT-CCI8 & 3.59 & 1.02 & -.529 & -.529 & .671 & \\
\hline ICT-CCI11 & 3.37 & 1.13 & -.174 & -.174 & .802 & \\
\hline ICT-CCI12 & 3.39 & 1.08 & -.237 & -.237 & .679 & \\
\hline ICT-CCI15 & 3.67 & 1.07 & -.585 & -.585 & .745 & \\
\hline ICT-CCI17 & 3.43 & 1.07 & -.392 & -.392 & .750 & \\
\hline CCI-Total & 3.45 & .89 & .323 & -.829 & & \\
\hline ICT-SCI6 & 3.59 & 1.27 & -.679 & -.651 & .791 & .916 \\
\hline ICT-SCI7 & 3.36 & 1.21 & -.404 & -.909 & .818 & \\
\hline ICT-SCI10 & 3.62 & 1.34 & -.641 & -.844 & .767 & \\
\hline ICT-SCI19 & 3.33 & 1.24 & -.306 & -.953 & .780 & \\
\hline ICT-SCI20 & 3.22 & 1.28 & -.284 & -1.062 & .764 & \\
\hline SCI-Total & 3.43 & 1.09 & -.557 & -.758 & & \\
\hline ICT General & 3.60 & .69 & -.144 & -.899 & & .893 \\
\hline
\end{tabular}

ICT = Information Communication Technology; TI= Traditional Integration, CCI= Cognitive Constructivist Integration; SCI $=$ Socio-Cultural Integration 
As a result of the descriptive analysis, the highest average value $(M=4.23, S D=.85)$ belongs to the 18 th item written under the dimension of Traditional Integration. The lowest average $(M=3.22, S D=1.28)$ belongs to the 20th item written under the dimension of Socio-Cultural Integration. When the item total correlations of the scale are examined, the lowest correlation $(r=.489)$ belongs to the 13th item under the dimension of Traditional Integration. The highest total item correlation $(\mathrm{r}=.818)$ belongs to the 10th item under the dimension of Socio-Cultural Integration. The item total correlation of the other items is between these values.

\section{CFA Analysis}

A Confirmatory Factor Analysis (CFA) was conducted to test usefulness of the scale in Kosovo culture based on the three-factor model of the scale. Chi-square $\left(x^{2}\right)$ value was determined as 463.33 and Degrees of Freedom $(d f=167)$ as the result of analysis. However, since some index values are low, 4 modifications were made. As a result of these modifications, some indices have achieved excellent results. The results of analysis are presented in Table 2 .

Table 2. Fit Indices Regarding CFA Results

\begin{tabular}{|c|c|c|c|c|c|c|c|c|c|c|}
\hline Name of Index & $x^{2} / \mathrm{df}$ & RMSEA & GFI & AGFI & $\mathrm{CFI}$ & NFI & NNFI & SRMR & RFI & IFI \\
\hline First CFA Value & $463.33 / 167=2.774$ & .078 & .86 & .83 & .96 & .94 & .95 & .062 & .93 & .96 \\
\hline 4 Modification & $372.88 / 162=2.301$ & .066 & .90 & .86 & .97 & .95 & .96 & .060 & .94 & .97 \\
\hline
\end{tabular}

According to the results of analysis, the indices of RMSEA $=.078$, GFI $=.86$, and AGFI $=.83$ are quite low in the generic (first) model, while other indexes $(\mathrm{NNFI}=.95, \mathrm{CFI}=.96$, and $\mathrm{IFI}=.96)$ are quite high. With the modifications made between items 12 to 15 and 5 to 15 under the dimension of CCI; 6 to 10 under the dimension of SCI; and 4 to 16 under the dimension of TI, an increase in some indices were observed. The Goodness of Fit Index (GFI) and the Adjusted Goodness Fit Index (AGFI) values, which were developed as an alternative to $x^{2}$ and not affected by sample size, are at the acceptable level. The standardized correlations between the TI, CCI, and SCI latent variables were significant and not all of the standardized values plotted in the path diagram were greater than 1 (Bentler \& Bonett, 1980; Tabachnick \& Fidell, 2007). The standardized path diagram is presented in Figure 1.

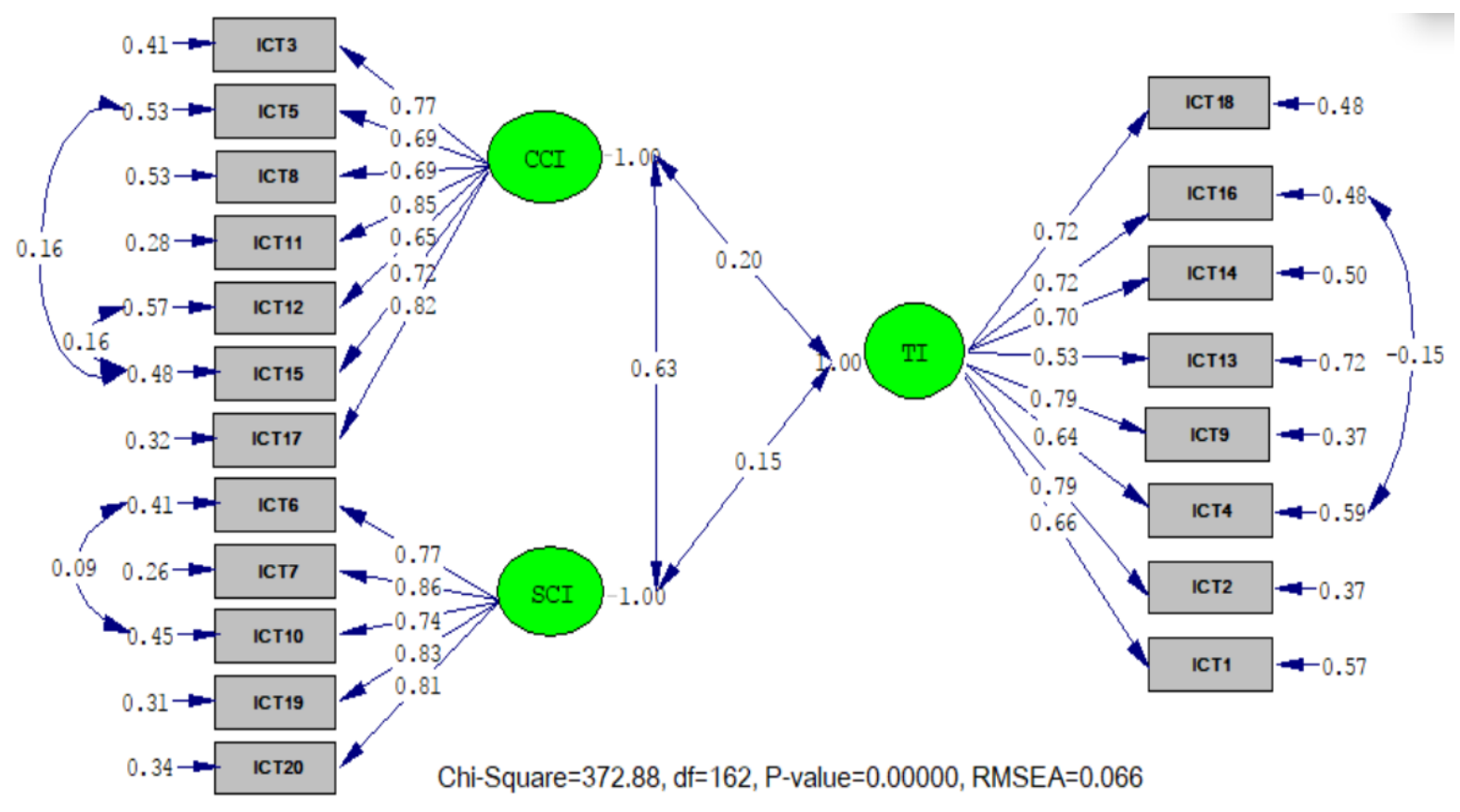

Figure 1. Standardized path diagram

As a result of CFA, all path coefficients of all the items in the determined dimensions are significant $(p<.05)$. In the Kosovo culture, it was determined that the ICT Integration Approach Scale was modeled with CCI, SCI and TI latent variables. Under the TI dimension, the lowest path coefficient belongs to 13th item with a value of .53 and the highest belongs to 4th and 9th item with a value of .79. Under the CCI dimension, the lowest path coefficient belongs to 12th item with a value of .65 and the highest belongs to 11 th item with a value of .85 . Under the SCI dimension, the lowest path coefficient belongs to 10th item with a value of .74 and the highest belongs to 7 th item with a value of .86 . 


\section{Correlation Analysis}

A correlation analysis was performed to determine the relationship between TI, CCI, and SCI dimensions of the scale. The results of analysis are presented in Table 3 .

Table 3. Correlation Analysis

\begin{tabular}{|cccc|}
\hline & Traditional Integration (TI) & Cognitive Constructivist Integration (CCI) & Socio-Cultural Integration (SCI) \\
\hline Cognitive Constructivist & $.217^{*}$ & & \\
$\quad$ Integration &, $295^{*}$ &, $549^{*}$ & $.859^{*}$ \\
Socio-Cultural Integration & $.512^{*}$ & $.790^{*}$ & \\
Overall Scale & & & \\
\hline
\end{tabular}

$*_{\mathrm{p}<01}$

In the correlation analysis performed between Traditional (TI), Cognitive Constructivist (CCI) and Socio-Cultural Integration (SCI) approaches, a positive correlation was found between all variables $(p<.05)$. The highest correlation $(r$ $=.55, p<.05)$ is between the Cognitive Constructivist and Socio-Cultural Integration approaches. The lowest correlation $(r=.22, p<.05)$ is between Traditional Integration and Cognitive Constructivist Integration approaches. There was also a moderate relationship between Socio-Cultural Integration and Traditional Integration $(r=.30, p<.05)$. Positive relations between all dimensions were determined. All subscales were found to have a significant positive correlation at the medium and high level.

\section{Determination of Item Discrimination}

To determine the item discrimination for each item of the scale, subscales and overall scale, data were analyzed using the upper group and lower group technique with a $27 \%$ criterion. As a result of the analysis, it was determined that all the items were discriminatory. The highest difference $\left(t_{160}=19.319, p<.05\right)$ between the upper group mean $(M=4.44, S D$ $=.59)$ and the lower group mean $(M=2.07, S D=.93)$ was at the 7th item. The lowest difference $\left(t_{160}=2.506, p<.05\right)$ between the upper group mean $(M=4.26, S D=.97)$ and the lower group mean $(M=3.63, S D=1.03)$ was at the 13th item. Significant differences were also found in the TI approach $\left(t_{160}=7.683, p<.05\right)$, in the CCI approach $\left(t_{160}=19.419, p\right.$ $<.05)$, and in the SCI approach $\left(t_{160}=27.747, p<.05\right)$ of the scale.

\section{ANOVA Results}

An ANOVA was conducted to analyze the effect of the weekly hours of ICT use for educational purposes on the integration approaches of instructors. The results of analysis are presented in Table 4.

Table 4. ANOVA Results

\begin{tabular}{|c|c|c|c|c|c|c|c|c|}
\hline & & $\mathrm{N}$ & M & $\mathrm{SD}$ & df & $\mathrm{F}$ & $\mathrm{p}$ & Scheffe \\
\hline \multirow{4}{*}{$\mathrm{TI}$} & a- None & 38 & 3.88 & .96 & 3 & 2.057 & .106 & \\
\hline & b- $1-2$ hour & 128 & 4.09 & .64 & 299 & & & \\
\hline & c- 3-5 hours & 91 & 4.16 & .62 & 302 & & & \\
\hline & d- More than 6 hours & 46 & 3.93 & .73 & & & & \\
\hline \multirow{4}{*}{$\mathrm{CCI}$} & a- None & 38 & 2.64 & .78 & 3 & 23.325 & $.000^{*}$ & $\mathrm{a}<\mathrm{b}<\mathrm{c} . \mathrm{d}$ \\
\hline & b- $1-2$ hour & 128 & 3.33 & .86 & 299 & & & \\
\hline & c- 3-5 hours & 91 & 3.71 & .79 & 302 & & & \\
\hline & d- More than 6 hours & 46 & 3.98 & .69 & & & & \\
\hline \multirow{4}{*}{$\mathrm{SCI}$} & a- None & 38 & 2.54 & 1.02 & 3 & 23.102 & $.000^{*}$ & $\mathrm{a}<\mathrm{b}<\mathrm{c} . \mathrm{d}$ \\
\hline & b- $1-2$ hour & 128 & 3.19 & 1.04 & 299 & & & \\
\hline & c- 3-5 hours & 91 & 3.79 & .99 & 302 & & & \\
\hline & d- More than 6 hours & 46 & 4.07 & .84 & & & & \\
\hline
\end{tabular}

${ }^{*} \mathrm{p}<.05$ 
As a result of the analysis for the difference between the frequency of ICT use for educational purposes and their approach of integration, there was not a difference in TI dimension of the scale $\left(F_{(3,302)}=2.057, p>.05\right)$. There was a significant difference in the CCI dimension $\left(F_{(3,302)}=\right.$ $23.325, \mathrm{p}<.05)$ and SCI dimension $\left(F_{(3,302)}=23.102, \mathrm{p}\right.$ $<.05)$ of the scale. $\mathrm{CCI}$ and SCI scores are increasing even more with the use of technology for educational purposes. In the $\mathrm{CCI}$ and $\mathrm{SCI}$ approaches, the average score of those who use technology for 3-5 hours and over 6 hours for educational purposes is higher than the average score of those who use technology for 1-2 hours, and the average score of those who use technology for 1-2 hours for educational purposes is higher than the average score of those who do not use technology.

\section{Discussion and Conclusions}

The study aimed to adapt the ICT integration scale to Kosovo culture. Firstly, the scale has been translated into Albanian and its appropriateness and clarity in terms of language has been checked. As a result of this review, no modifications have been made in Albanian version. It is clear that when the scale is applied in a different culture and a different language, failing to achieve linguistic equivalence may lead to problems in the fit indices and model fit obtained as a result of CFA. As a matter of fact, Stes, De Mayer, and van Petegem (2010), in their work towards Validation of a Dutch Version of the Approaches to Teaching Inventory, pointed out the problems stemming out of language and therefore cultural differences. For this reason, it can be said that it is important to provide linguistic equivalence in order to minimize the problems based on the fit indices resulting from linguistic problems. In this study, the scale intended to be adapted from Turkish to Albanian was translated by expert translators and then both versions were applied to five instructors who speak Turkish and Albanian and teach in these languages. The results obtained from this application were similar. Experts declared that the statements in both languages are the same. It was decided that the Albanian translation of the scale developed in Turkish was sufficient.

The reliability analysis results based on the three-factor structure of the scale were found to be quite high. The Cronbach's Alpha value was .88 for TI dimension, was .91 for the CCI dimension, was .92 for the SCI dimension, and was .89 for the overall scale. The lowest correlation value in the analysis of item-total correlations was .489 for 13th item under the dimension of TI (I use computer and Internet technologies for writing, planning, and recording purposes), and the highest correlation was . 818 for 7 th item under the dimension of SCI (Students share their presentations through tools such as electronic message boards, blogs, and wikis). The item-total correlation values of other items are in this range. The results of Cronbach's
Alpha analysis and item analysis in this study were higher than the results obtained in the Tezci (2016) study. Tezci (2016), in his study, found The Cronbach's Alpha value for the overall scale as 0.80 , for the TI dimension as .80 , for the CCI dimension as .79, and for the SCI dimension as .74. It was determined that both the items and subscales of the scale and the general average were discriminatory in the analysis with the upper group and lower group technique.

According to the first CFA results of the scale, fit indices that were not very high were obtained. For this reason, it has been decided to make modifications in the error variances. As a result of the modifications made between 4th and 16th items under the TI dimension, 15th, 12th, and 5th items under the CCI dimension, and 6th and 10th items under the SCI dimension, some of the fit indices achieved better results. The RMSEA value has fallen from .078 to .066 . GFI value rose from .86 to .90 , CFI value from .96 to .97 , NFI value from .94 to .95 , and NNFI value from .95 to .96 . The SRMR value also dropped from .062 to .060 . According to the results of CFA, it was observed that the path coefficients of all the items are meaningful. The lowest path coefficient belongs to 13th item under the TI dimension with a value of .53 (I use computer and Internet technologies for writing, planning, and recording purposes). The highest path coefficient belongs to the 11th item under the CCI dimension with a value of .85 (My students keep digital/electronic portfolios). The path coefficients of other items are between these values. It can be said that the factor structures determined in the Turkish sample of the scale support a similar structure in Kosovo culture. The fit index values obtained in this study are close to that of the Tezci (2016) study. It can be said that providing the linguistic equivalence of the scale can be an important factor in supporting the same results in the Kosovo culture with the original of the factor structures. It can be said that in cases where linguistic equivalence cannot be achieved in researches made in different cultures, the probability of having different factorial structures may increase. Stes et al. (2010) and Meyer and Eley (2006) investigated the effect of linguistic differences on factorial structures of the scale. Beaton et al. (2000) discussed different approaches to scale adaptation in cross-cultural studies. They pointed to the importance of adaptation for studies to be done in countries that are linguistically and culturally different. Although Kosovo culture is similar to Turkish culture in terms of certain characteristics, the native language of the instructors in the research sample is Albanian. The data were collected from instructors who teach in Albanian.

Correlations between subscales of the scale were positive and moderate. There was a positive and close to moderate relationship between the dimension of TI and the dimensions of CCI and SCI, and a positive and moderate relationship between the dimension of $\mathrm{CCI}$ and the dimension of SCI. In the Tezci (2016) study, there was a low but negative relationship between the dimension of TI and the dimensions of CCI and SCI, and a positive and 
moderate relationship between the dimension of $\mathrm{CCI}$ and the dimension of SCI. Differences between correlations suggest that these differences may arise because of the sample group. These results show that the scale can be used to determine approaches in a general sense, rather than to classify or categorize teachers in terms of ICT integration approaches. This scale will help you understand in what context teachers are addressing technology rather than classifying a school in terms of ICT integration approach.

Another result of the research is the relationship between the frequency for instructors' use of tools and software related to ICT and their integration approaches. According to the frequency of ICT use, the approach of using ICT based on TI understanding for educational purposes does not differ. CCI and SCI approaches have, however, been found to differ according to the frequency of ICT use per week. Significant differences were found between those who did use ICT or use it very limited (1-2 hours per week) and those who used it more often. The average of CCI and SCI approaches for those who did not use ICT or use it very limited is lower. It is clear that ICT requires more use for educational purposes in terms of $\mathrm{CCI}$ and SCI, and that there is a necessity of a school culture in this direction. Because of the lack of a scale based on ICT integration approach in the literature, frequency of ICT use is used as criterion-related validity. Along with this, it might be useful to consider the relationship between ICT and the related software types and tools. However, such data were not gathered in this survey. Tay, Lim, Lim, and Koh (2012) determined that there is relationship between the frequency for instructors' use of ICT and their pedagogical approach to ICT use. Tezci (2011a, 2011b) determined the relationship between frequency of ICT use and perceived school climate and support. In this study, it was determined that those who use ICT more than 3-5 hours and 6 hours for educational purposes have higher average than those who use ICT at a lower level in terms of Cognitive Constructivist and Socio-Cultural approach. Hosein, Ramanau and Jones (2010) determined that the purpose and frequency of ICT use is related to the knowledge of ICT-related tools. Hsu (2011) found that lower frequency of ICT use is associated with simple tasks given to the students, while higher frequency of ICT use is associates with shared ICT-based activities. It can be said that the results of this research are consistent with Hsu's study when simple tasks, such as information transfer, are considered in a traditional context and learning with technology through ICT-based activities and cooperative is considered in a cognitive and socio-cultural context (Jonassen, 2000; Ringstaff \& Kelley, 2002).

Teachers' adaptation of ICT based on socio-cultural context requires a technology-based learning environment and culture (Yuen, 2000). This requires a design of technology as a learning tool for learners rather than a tool for knowledge transfer (Doornekamp, 2002). Gajendran and Brewer (2007) discussed the effect of institutional culture on the integration of ICT. Tay, Lim, and Lim (2013) determined that the beliefs and practices of the teacher were effective in the ICT integration in the teaching and learning process in the class. For this reason, it can be said that the perspectives of the teachers for the use of technology and their tendencies are important (Tezci, Erdener, \& Atici, 2016). On the other hand, the school culture has an important influence on teachers' behaviors. Indeed, Tondeur, van Keer, van Braak, and Valcke (2008) have also identified that support ICT use, education and school policies have an influence on the ICT use in the classroom. In this study, the socio-cultural approach was taken as a reflection of an understanding that included school policies. Some of the ICT-based activities that Lim and Chai (2004) described in their qualitative research can be addressed from TI perspective, while some of them can be addressed from the CCI perspective. Therefore, it can be said that the scale discussed in this study is similar to the approach that Lim and Chai addressed in their study. Law (2009) identified the relationship between teachers' pedagogical approaches and ICT integration approaches. Teachers who adopt the traditional pedagogical approach integrate ICT on the basis of information transmission.

The items in the TI dimension of the scale reflect technology integration as content distribution and the items in the dimensions of CCI and SCI reflect technology integration based on constructivist understanding. Bower, Hedberg, and Kuswara's (2010) suggestion of transmitter approach about technology and learning with technology is consistent with the view of the TI dimension in this study, and their suggestion of dialogic, constructionist and co-constructive approach is consistent with the view of the $\mathrm{CCI}$ and SCI dimensions in this study. In some studies in the literature related to ICT (Akbulut, 2010; Dexter, Seashore \& Anderson, 2002; Hsu, 2010), it has been observed that the use of technology related software could be addressed in TI context, and in some other studies it could be addressed in CCI and SCI contexts. Teachers' ICT-related activities, their use of software, and their approach to technology are an indication of the context in which they integrate ICT. The context of the teachers' approach to integration can be considered as a reflection of this culture. From this perspective, it can be seen that the ICT integration approach scale can be used in Kosovo culture to identify Albanian-speaking teachers' technology integration approaches in the teaching and learning process.

The investigating the validity and reliability of the scale adapted in this study in different cultures will contribute to the internationalization of the scale. An examination of the relationship between teacher's teaching and learning understanding of the scale may contribute to understanding of the nature of the relationship between the technology integration approach and teaching understanding. One of the limitations of this research is that the measure considered for criterion-related validity is not a strong 
criterion. It will be useful to examine the criterion validity of the scale by specifying different criteria.

\section{Appendix 1: Turkish version of ICT Scale}

1- BİT'i bilgi aktarmak için kullanmaktayım

16- BİT'i öğrencilerimin bireysel etkinlikler yapmaları/öğrenmeleri için tasarlarım

18- Bilgi ve iletişim teknolojilerini öğrencilerin öğrenmelerinde yardımcı bir araç olarak kullanırım 13-Bilgisayar ve internet teknolojileri yazma, plan yapma, kayıt tutma gibi amaçlarla kullanırım

2- PowerPoint gibi sunum araçları ile dersi öğretmekteyim 9-Sınıfta çoklu ortam (multimedia) araçlarını içeriği daha somut-görsel hale getirmek için kullanıyorum

4-BİT'i içeriği görselleştirip bilgileri aktarmak için kullanmaktayım

14-BİT'i gösterim aracı olarak kullanmaktayım

8- Öğrencilerim, öğrendiklerini sergilemek için teknolojiyi kullanırlar

11- Öğrencilerim dijital/elektronik portfolyo tutarlar

17-Bilgi ve iletişim teknolojilerini ağ araştırması (webquest) gibi uygulamalar yapmada kullanırım

15-Bilgi ve iletişim teknolojilerini öğrencilerim sınıfta görevleri-etkinlikleri yapmada kullanırlar

12-Teknoloji, gerçek yaşam durumlarını (otantiklik) sağlamada (senaryoların, örnek olayların vb sunumunda) kullanmaktayım

5-Öğrencilerim MS Ofis, animasyon, film yapma (Word, Excel, animator, Flash gibi) yazılımları kullanarak içeriği kendileri oluştururlar

3-Öğrencilerim sınıfta internet kullanarak enformasyona (bilgiye) erişim yaparlar

20- BİT öğrencilerin birbirlerinden öğrenmeleri için kullanıyorum (forum, blog, wiki gibi ortamlarda içerik oluşturma, tartışma)

19-Öğrenciler ve öğretmenler BíT ile (forum, blog gibi ortamlarda) ders dışı zamanlarda da öğrenmeyle ilgili etkinliklere dayalı iletişim kurarlar

7-Elektronik mesaj tahtaları, blog, wiki gibi araçlarla öğrenciler sunumlarını paylaşırlar

6- BİT'i kullanarak öğrencilerim birbirleriyle/başkalarıly dosya ve mesaj paylaşımı yaparlar (öğrendikleri ve ya öğrenecekleri konularda)

10- Teknoloji kullanarak öğrencilerim takım halinde çalışıp proje yaparlar

\section{Appendix 2: Albanian Version of ICT Scale}

\begin{tabular}{|c|c|c|c|c|c|}
\hline & $\begin{array}{l}\text { Plotësisht } \\
\text { pajtohem }\end{array}$ & Pajtohem & I pavendosur & $\begin{array}{c}\text { Nuk } \\
\text { pajtohem }\end{array}$ & $\begin{array}{c}\text { Plotësisht nuk } \\
\text { pajtohem }\end{array}$ \\
\hline \multicolumn{6}{|l|}{ 1- TIK-un e përdori për të transferuar informata. } \\
\hline \multicolumn{6}{|l|}{$\begin{array}{l}\text { 16- Bëjë integrimin e TIK-ut që t’ua mundësoj nxënësve të bëjnë (mësojnë) } \\
\text { aktivitete individuale. }\end{array}$} \\
\hline \multicolumn{6}{|l|}{$\begin{array}{l}\text { 18- Teknologjitë e informacionit dhe komunikimit i përdori si një mjet për t’ } \mathrm{i} \\
\text { ndihmuar nxënësit në të nxënë. }\end{array}$} \\
\hline \multicolumn{6}{|l|}{$\begin{array}{l}\text { 13-Internetin dhe kompjuterin e shfrytëzoj për shkrim, planifikimi, } \\
\text { memorizimin e të dhënave. }\end{array}$} \\
\hline \multicolumn{6}{|l|}{ 2- Në mësimdhënie përdor programe të prezantime sikurse është PowerPoint. } \\
\hline \multicolumn{6}{|l|}{ 9-Përdor mjete multimediale për konkretizimin-vizualitetin të përmbajtjes. } \\
\hline \multicolumn{6}{|l|}{ 4-Shfrytëzoj TIK-un për transferimin e përmbajtjes në mënyrë vizuale. } \\
\hline \multicolumn{6}{|l|}{ 14-Përdor TIK-un si mjet prezantues. } \\
\hline \multicolumn{6}{|l|}{ 8- Nxënësit përdorin teknologjitë për t’i ekspozuar të nxënit e tyre. } \\
\hline \multicolumn{6}{|l|}{ 11- Nxënësit posedojnë dosje (portfolio) elektronike. } \\
\hline \multicolumn{6}{|l|}{$\begin{array}{l}\text { 17-Bëjë shfrytëzimin e teknologjisë së informacionit dhe internetin në rrjetet e } \\
\text { kërkimit (WebQuest). }\end{array}$} \\
\hline \multicolumn{6}{|l|}{$\begin{array}{l}\text { 15-Nxënësit aplikojnë teknologjinë informative në kryerjen e detyrave dhe } \\
\text { aktiviteteve të dhëna. }\end{array}$} \\
\hline \multicolumn{6}{|l|}{$\begin{array}{l}\text { 12-Shfrytëzoj teknologjinë (për skenarë, prezantime) të marra nga situatat e jetës } \\
\text { reale. }\end{array}$} \\
\hline \multicolumn{6}{|l|}{$\begin{array}{l}\text { 5-Nxënësit krijojnë përmbajtje duke përdorur programe si MS Office, } \\
\text { animacione, filma (Word, Excel, Flash). }\end{array}$} \\
\hline 3-Duke përdorur internetin nxënësit nga klasa mund të qasen në informacione. & & & & & \\
\hline
\end{tabular}




\begin{tabular}{|l|l|l|l|l|}
\hline $\begin{array}{l}\text { 20- Bëjë shfrytëzimin e TIK-ut (forumeve, blogjeve, wiki) në mënyrë që } \\
\text { nxënësit të mësojnë nga njëri-tjetri }\end{array}$ & & & & \\
\hline $\begin{array}{l}\text { 19-Edhe jashtë programit mësimor nxënësit dhe mësimdhënësit nëpërmjet } \\
\text { TIK-ut (forumeve, blogjeve) komunikojnë lidhur me aktivitetet dhe mësimet. }\end{array}$ & & & \\
\hline $\begin{array}{l}\text { 7-Nxënësit shpërndajnë postimet e tyre duke përdorur mjete si : tabelat e } \\
\text { mesazheve elektronike, blogjet, wiki. }\end{array}$ & & & & \\
\hline $\begin{array}{l}\text { 6- Duke shfrytëzuar TIK-un nxënësit bëjnë shkëmbimin e dosjeve dhe } \\
\text { mesazheve (të njësive të mësuara) me njëri-tjetrin dhe me të tjerët }\end{array}$ & & & \\
\hline 10- Duke shfrytëzuar teknologjinë nxënësit në formë grupore punojnë projekte. & & & & \\
\hline
\end{tabular}

\section{Appendix 3: English Version of ICT Scale}

1- I use ICT to transfer information

16- I design ICT to enable my students to do (learn) individual activities.

18- I use information and communication technologies as a tool to help learners learn.

13- I use computer and Internet technologies for writing, planning, and recording purposes.

2- In teaching, I use presentation programs such as PowerPoint.

9- I use multimedia tools to embody (visualize) the content.

4- I use ICT to visualize and transfer the content.

14- I use ICT as a presentation tool.

8- My students use technology to show what they have learned.

11- My students keep a digital/electronic portfolio.

17- I use information and communication technologies in practices such as webquest.

15- My students use information and communication technologies to perform tasks-activities in the classroom.

12- I use technology to provide (authentication) real-life situations such as scenarios, case studies, etc.

5- My students create content themselves using programs such as MS Office, animation, movie maker (Word, Excel, Flash).

3- My students access the information by using the Internet in the class.

20- I use ICT for students to learn from each other (creating content and discussing in environments such as forums, blogs, and wiki).

19- Students and teachers communicate through ICT (in environments such as forums and blogs) based on activities related to learning in extracurricular times.

7- Students share their presentations through tools such as electronic message boards, blogs, and wikis.

6- By using ICT, my students share files and messages with each other/others (on topics they learned or will learn).

10- By using technology, my students work in teams and make projects.

\section{REFERENCES}

[1] Akbulut, Y. (2010). Structural model proposal for Turkish faculties of education regarding ICT integration indicators. Contemporary Educational Technology, 1(4), 322-334.

[2] Albirini, A. A. (2006). Teachers' attitudes toward information and communication technologies: The case of Syrian EFL teachers. Computers \& Education, 47(4), 373398.

[3] Asan, T., Ekşi, F., Doğan, A., \& Ekşi, H. (2013). Bireysel Değerler Envanteri'nin dilsel eşdeğerlik geçerlik ve güvenirlik çalışması. Ĕğitim Bilimleri Dergisi, 27(27), $15-38$.

[4] Bayram, N. (2010). Yapısal eşitlik modellemesine giriş. Bursa: Ekin Kitabevi.

[5] Beaton, D. E., Bombardier, C., Guillemin, F., \& Ferraz, M. B. (2000). Guidelines for the process of cross-cultural adaptation of self-report measures. Spine, 25(24), 3186-3191.

[6] Becta (2007). Harnessing technology: Progress and impact of technology. Retrieved from http://publications. becta.org. $\mathrm{uk} /$ displaycfm?resiD $=33979$ \&page $=1835$

[7] Bentler, P. M., \& Bonett, D. G. (1980). Significance tests and goodness of fit in the analysis of covariance structures. Psychological Bulletin, 88(3), 588-606.

[8] Bollen, K. A. (1989). A new incremental fit index for general structural equation models. Sociological Methods \& Research, 17(3), 303-316.

http://dx.doi.org/10.1177/0049124189017003004.

[9] Bower, M., Hedberg, J. \& Kuswara, A. (2010). A framework for Web 2.0 learning design. Educational Media International, 47(3), 177-198. http://dx.doi.org/10.1080/09523987.2010.518811.

[10] Brantley-Dias, L., \& Ertmer, P. A. (2013). Goldilocks and TPACK: Is the construct 'just right?'. Journal of Research on Technology in Education, 46(2), 103-128.

[11] Britten, J. S. \& Cassady, J. C. (2005). The technology integration assessment instrument: Understanding planned use of technology by classroom teachers. Computers in the Schools, 22(3), 49-61.

[12] Büyüköztürk, Ş., Şekercioğlu, G., \& Çokluk, O. (2014). Sosyal bilimler için çok değişkenli istatistik: SPSS ve LISREL uygulamalart. Ankara: Pegem Akademi Yay. 
[13] Carlson, S., \& Gadio, C. T. (2002). Teacher professional development in the use of technology. In W.D. Haddad \& A. Draxler (Eds.), Technologies for education: potential, parameters, and prospects (pp. 118-132). Paris and Washington, D.C.: UNESCO and AED. http://www.schoolnetafrica.net/fileadmin/resources/Teacher _Professional_Development_In_the_use_of_Techno logy.pdf. Accessed, 21 May 2017.

[14] Carmines, E. G., \& Zeller, R. A. (1979). Reliability and validity assessment (Vol. 17). Sage publications.

[15] Davis, N., Preston, C., \& Sahin, I. (2009). ICT teacher training: Evidence for multilevel evaluation from a national initiative. British Journal of Educational Technology, 40(1), $135-148$.

[16] Dexter, S., Seashore, K. R., \& Anderson, R. E. (2002). Contributions of professional community to exemplary use of ICT. Journal of Computer Assisted Learning, 18(4), 489-497.

[17] Doornekamp, G. (2002). A comparative study on ICT as a tool for the evaluation of the policies on ICT in education. Studies in Educational Evaluation, 28(3), 253-271.

[18] Erdener, M. A., \& Gül, Ö. (2017). Investigation of elementary school teachers' perceptions relating to lifelong learning. Necatibey Faculty of Education Electronic Journal of Science \& Mathematics Education, 11(2), 545-563.

[19] Ertmer, P. (1999). Addressing first- and second-order barriers to change: Strategies for technology integration. Education Technology Research and Development, 47(4), 47-61.

[20] Ertmer, P. A., \& Ottenbreit-Leftwich, A. (2013). Removing obstacles to the pedagogical changes required by Jonassen's vision of authentic technology-enabled learning. Computers \& Education, 64, 175-182.

[21] European Commission. (2000). eEurope: An information society for all. Brussels, Belgium: European Commission.

[22] European Commission (2001). Survey report: Students' perceptions of the use of ICT in university learning and teaching. 8 July 2011: http://www.spotplus.odl.org/downlo ads/Survey_report_final.pdf

[23] Eurydice. (2004). Key data on information and communications technology in schools in Europe. Brussels, Belgium: Eurydice.

[24] Fullan, M. (2002). The change leader. Educational Leadership, 59(8), 16-21.

[25] Gajendran, T., \& Brewer, G. (2007). Integration of information and communication technology: Influence of the cultural environment. Engineering, Construction and Architectural Management, 14(6), 532-549. DOI: https://doi.org/10.1108/09699980710829003

[26] Geisinger, K. F. (1994). Cross-cultural normative assessment: Translation and adaptation issues influencing the normative interpretation of assessment instruments. Psychological Assessment, 6(4), 304-312. http://dx.doi.org/ 10.1037/1040-3590.6.4.304.

[27] Gillani B. B. (2000). Culturally responsive educational web sites. Educational Media International, 37, 185-195.
[28] Hannover Research. (2014). Professional development for technology integration. NW, Washington DC: Hannover Research Project.

[29] Heemskerk, I., Brink, A., Volman, M., \& Ten Dam, G. (2005). Inclusiveness and ICT in education: a focus on gender, ethnicity and social class. Journal of Computer Assisted Learning, 21(1), 1-16.

[30] Hermans, R., Tondeur, J., van Braak, J., \& Valcke, M (2008). The impact of primary school teachers' educational beliefs on the classroom use of computers. Computers \& Education, 51(4), 1499-1509.

[31] Hosein, A., Ramanau, R., \& Jones, C. (2010). Learning and living technologies: A longitudinal study of first- year students' frequency and competence in the use of ICT. Learning, Media and Technology, 35(4), 403-418.

[32] Hoyle, R. H. (Ed.). (1995). Structural equation modeling: Concepts, issues, and applications. Thousand Oaks, California: Sage Publications.

[33] Hsu, S. (2010). Developing a scale for teacher integration of information and communication technology in grades 1-9. Journal of Computer Assisted Learning, 26(3), 175-189.

[34] Hsu, S. (2011). Who assigns the most ICT activities? Examining the relationship between teacher and student usage. Computers \& Education, 56(3), 847-855.

[35] Iyengar, S. (1993). Assessing linguistic equivalence in multilingual surveys. Social research in developing countries: Surveys and censuses in the third world (pp.173-82). London: John Wiley \& Sons.

[36] Jonassen, D., Howland, J., Marra, R., \& Crismond, D. (2008). Meaningful learning with technology (3rd ed.). Upper Saddle River, NJ: Pearson.

[37] Jonassen, D. H. (2000). Computers as mind tools for schools: Engaging critical thinking (2nd Ed.). Upper Saddle River, New Jersey: Merrill/Prentice Hall.

[38] Jonassen, D. H. (1991). Objectivism versus constructivism: Do we need a new philosophical paradigm? Educational Technology Research and Development, 39(3), 5-14.

[39] Jöreskog, K. G., \& Sörbom, D. (1996). LISREL 8: User's reference guide. Scientific Software International.

[40] Jung, I. (2005). ICT-pedagogy integration in teacher training: Application cases worldwide. Educational Technology \& Society, 8(2), 94-101.

[41] Koehler, M. J., \& Mishra, P. (2009). What is technological pedagogical content knowledge? Contemporary Issues in Technology and Teacher Education, 9(1), 60-70.

[42] Koh, J. H. L., Chai, C. S., \& Lim, W. Y. (2017). Teacher professional development for TPACK-21CL: Effects on teacher ICT integration and student outcomes. Journal of Educational Computing Research, 55(2), 172-196.

[43] Kozma, R. B. (2005). National policies that connect ICT-based education reform to economic and social development. Human Technology, 1(2), 117-156.

[44] Law, N. (2009). Mathematics and science teachers' pedagogical orientations and their use of ICT in teaching. Education and Information Technologies, 14(4), 309-323. 
http://dx.doi.org/10.1007/s10639-009-9094-z.

[45] Law, W. W. (2004). Translating globalization and democratization into local policy: Educational reform in Hong Kong and Taiwan. International Review of Education, 50, 497-524.

[46] Lim, C. P., \& Chai, C. S. (2004). An activity-theoretical approach to research of ICT integration in Singapore schools: Orienting activities and learner autonomy. Computers \& Education, 43(3), 215-236.

[47] Lim, C. P. \& Chai, C. S. (2008). Teachers' pedagogical beliefs and their planning and conduct of computer-mediated classroom lessons. British Journal of Educational Technology, 39(5), 807-828.

[48] Liu, L., Maddux, C., \& Johnson, L. (2008). Assessment of integration of technology in education: Countering the "no significant differences" argument. Computers in the Schools, 25(1/2), 1-9.

[49] Maddux, C. D., \& Johnson, D. L. (2006). Type II applications of information technology in education: The next revolution. Computers in the Schools, 23(1/2), 1-6.

[50] Maddux, C. D., \& Johnson, D. L. (2005). Information technology, type II classroom integration, and the limited infrastructure in schools. Computers in the Schools: Interdisciplinary Journal of Practice, Theory, and Applied Research, 22(3-4), 1-5.

[51] Maddux, C. D., Johnson, D. L., \& Willis, J. W. (2001). Educational computing: Learning with tomorrow's technologies (3rd Ed. Boston). MA: Allyn and Bacon.

[52] MAShT. (2016). Korniza e kurrikules e arsimit parauniversitar të Republikës së Kosovës (e Rishikuar). Prishtinë: Blendi.

[53] MAShT. (2012). Kurrikula bërthamë për arsimin e mesëm të ulët (Klasa VI,VII,VIII,IX). Prishtinë: Grafika Rezniqi.

[54] MAShT. (2011). Korniza e Kurrikules e Arsimit Parauniversitar të Republikës së Kosovës. Prishtinë: Grafika Rezniqi.

[55] Meyer, J. H. F., \& Eley, M. G. (2006). The Approaches to teaching inventory: A critique of its development and applicability. British Journal of Educational Psychology, 76, 633-649. http://dx.doi.org/10.1348/000709905X49908

[56] Mishra, P., \& Koehler, M. J. (2006). Technological pedagogical content knowledge: A framework for teacher knowledge. Teachers College Record, 108(6), 1017-1054.

[57] OECD. (2017). OECD economic survey: Slovak Republic 2017. Paris: OECD Publishing.

Doi:10.1787/eco_survey-svk-2017-en.

[58] Ottenbreit-Leftwich, A. T., Ertmer, P. A., \& Tondeur, J. (2015). Interpretation of research on technology integration in teacher education in the USA: Preparation and current practices. In International handbook of interpretation in educational research (pp. 1239-1262). Springer, Dordrecht.

[59] Palak, D., \& Walls, R. T. (2009). Teachers' beliefs and technology practices: A mixed-methods approach. Journal of Research on Technology in Education, 41(4), 417-441.

[60] Palincsar, A. S. (1998). Social constructivist perspectives on teaching and learning. Annual Review of Psychology, 49(1), 345-375.

[61] Reeves T. C. (1997). An evaluator looks at cultural diversity. Educational Technology, 37, 27-30.

[62] Richardson, J. W. (2008). ICT in education reform in Cambodia: problems, politics, and policies impacting implementation. Information Technologies \& International Development, 4(4), pp-67.

[63] Ringstaff, C., \& Kelley, L. (2002). The learning return on our educational technology investment: A review of findings from research. San Francisco: WestEd. http://www.wested.org/online_pubs/learning_return.pdf

[64] Sahlberg, P. (2006). Education reform for raising economic competitiveness. Journal of Educational Change, 7(4), 259-287.

[65] Schellhase, K. C. (2009). Are approaches to teaching and/or student evaluation of instruction scores related to the amount of faculty formal educational course work? (Unpublished $\mathrm{PhD}$ dissertation). College of Education at the University of Central Florida Orlando, Florida.

[66] Shamir-Inbal, T., \& Avidov-Ungar, O. (2013). Empowerment patterns of leaders in ICT and school strengths following the implementation of national ICT reform. Journal of Information Technology Education, 12, 141-158.

[67] Selwyn, N. (2008). Realising the potential of new technology? Assessing the legacy of New Labour's ICT agenda 1997-2007. Oxford Review of Education, 34(6), 701 -712 .

[68] Stes, A., De Maeyer, S., \& Van Petegem, P. (2010). Approaches to teaching in higher education: Validation of a Dutch version of the Approaches to Teaching Inventory. Learning Environments Research, 13(1), 59-73. http://dx.doi.org/10.1007/s10984-009-9066-7.

[69] Tabachnick, B. G., \& Fidell, L. S. (2007). Using Multivariate Statistics (5th ed.). New York: Allyn and Bacon.

[70] Tay, L. Y., Lim, S. K., \& Lim, C. P. (2013). Factors affecting the ICT integration and implementation of one-to-one computing learning environment in a primary school-A sociocultural perspective. In Creating Holistic Technology-Enhanced Learning Experiences (pp. 19-37). Sense Publishers, Rotterdam.

[71] Tay, L. Y., Lim, S. K., Lim, C. P., \& Koh, J. H. L. (2012). Pedagogical approaches for ICT integration into primary school English and mathematics: A Singapore case study. Australasian Journal of Educational Technology, 28(4), 740-754.

[72] Taylor, G. J., Bagby, R. M., \& Parker, J. D. (2003). The 20-Item Toronto Alexithymia Scale: IV. Reliability and factorial validity in different languages and cultures. Journal of psychosomatic research, 55(3), 277-283.

[73] Tezci, E. (2016). Öğretmenlerin BIT entegrasyon yaklaşımlarının ölçülmesi. Kastamonu Eğitim Dergisi, 24(2), 975-992.

[74] Tezci, E. (2011a). Factors that influence pre-service teachers' ICT usage in education. European Journal of Teacher 
Education, 34(4), 483-499.

[75] Tezci, E. (2011b). Turkish primary school teachers' perceptions of school culture regarding ICT integration. Educational Technology Research and Development, 59(3), 429-443.

[76] Tezci, E. (2009). Teachers' effect on ICT use in education: The Turkey sample. Procedia-Social and Behavioral Sciences, 1(1), 1285-1294.

[77] Tezci, E., Erdener, M. A., \& Atici, S. (2016). The Effect of pre-service teachers' epistemological beliefs on teaching approaches. Universal Journal of Educational Research, 4(12), 205-215.

[78] Toh, Y., \& So, H. J. (2011). ICT reform initiatives in Singapore schools: A complexity theory perspective. Asia Pacific Education Review, 12(3), 349-357.

[79] Tondeur, J., Hermans, R., van Braak, J., \& Valcke, M. (2008). Exploring the link between teachers' educational belief profiles and different types of computer use in the classroom. Computers in Human Behavior, 24(6), 2541-2553.

[80] Tondeur, J., Van Keer, H., van Braak, J., \& Valcke, M. (2008). ICT integration in the classroom: Challenging the potential of a school policy. Computers \& Education, 51(1), 212-223.

[81] Van Melle, E., Cimellaro, L., \& Shulha, L. (2003). A dynamic framework to guide the implementation and evaluation of educational technologies. Education and Information Technologies, 8(3), 267-285.

[82] Vygotsky, L. S. (1978). Mind in society. Cambridge, MA: Harvard University Press.
[83] Woo, Y., \& Reeves, T. C. (2007). Meaningful interaction in web-based learning: A social constructivist interpretation. The Internet and Higher Education, 10(1), 15-25.

[84] Ward, L., \& Parr, J. M. (2010). Revisiting and reframing use: Implications for the integration of ICT. Computers \& Education, 54(1), 113-122.

[85] Windschitl, M. (2002). Framing constructivism in practice as the negotiation of dilemmas: An analysis of the conceptual, pedagogical, cultural, and political challenges facing teachers. Review of Educational Research, 72(2), 131-175.

[86] World Bank. (2010). Information and communication technology expenditure (\% of $G D P)$. http://data.worldbank.org/indicator/IE.ICT.TOTL.GD.ZS. Accessed 15 May 2010.

[87] Wren, A. (2017). Social investment and the service economy trilemma. Hemerijck, A. (Ed.). (2017). The uses of social investment. (pp. 97-107). UK: Oxford University Press.

[88] Yuen, H. K. (2000). ICT implementation at the school level. In N. Law, H. K. Yuen, W. W. Ki, S. C. Li, Y. Lee, \& Y. Chow (Eds.), Changing classroom and changing schools: Study of good practices in using ICT in Hong Kong schools (pp. 119-124). Hong Kong: Centre for Information Technology in School and Teacher Education, The University of Hong Kong.

[89] Yuen, H. K. \& Chow, Y. (2000). Social-constructivist perspectives. In N. Law, H. K. Yuen, W. W. Ki, S. C. Li, Y.Lee, \& Y. Chow (Eds.), Changing classroom and changing schools: Study of good practices in using ICT in Hong Kong schools (pp. 119-124). Hong Kong: Centre for Information Technology in School and Teacher Education, The University of Hong Kong. 